\title{
Cognitive Abilities, Debt, Roads and their Impact on Deaths in Traffic in Brazil
}

\author{
Rodrigo Focosi Mazzei* @, Camila Lemos Batista @, Mayra Antonelli-Ponti @, \\ Sérgio Sheiji Fukusima (1), \& José Aparecido da Silva (1) \\ Universidade de São Paulo, São Paulo, SP, Brazil
}

\begin{abstract}
Deaths in traffic represent a global and multicausal problem. We verified, through a linear regression model, that cognitive abilities (CA) and population indebtedness (PI) predict, together, $56 \%$ of the variation of death rates in the traffic (DT) of the twenty-seven states of Brazil. CA's are related to a greater control of the attention and, possibly, to a greater compliance with norms for preventing traffic accidents, has a greater impact than PI on DT, since PI associates to only one deficit of people's attention resources. The decrease of PI and the improvement of CA can decrease DT.
\end{abstract}

KEYWORDS: PISA, debt, drivers, vehicles, deaths

\section{Habilidades Cognitivas, Endividamento, Rodovias e seus Impactos nos Óbitos no Trânsito}

\begin{abstract}
RESUMO - Os óbitos no trânsito representam um problema global e multicausal. Verificamos, por meio de um modelo de regressão linear, que as habilidades cognitivas (HC) e o endividamento populacional (ENDP), predizem, juntos, $56 \%$ da variação das taxas de óbitos no trânsito (TOT) das 27 unidades federativas (UF) do Brasil. As HC, por estarem relacionadas a um maior controle da atenção e, possivelmente, a um maior cumprimento de normas de prevenção contra acidentes de trânsito, possuem um impacto maior que o ENDP sobre as TOT, já que o ENDP associa-se somente a um déficit dos recursos de atenção das pessoas. A diminuição do ENDP e a melhoria das HC podem reduzir as TOT.
\end{abstract}

PALAVRAS-CHAVE: PISA, dívida, motoristas, veículos, mortes

\section{INTRODUCTION}

Multiple studies have investigated the correlations between the cognitive abilities (CA) of populations from different regions of the planet and their respective social indicators, highlighting that bigger average cognitive ability in the inhabitants of geographical location predicts their respective social indicators, such as, Gross Domestic Product (GDP) per capita, more years of education completed, high life expectancy, and greater levels in the Democracy Index as well as in the Human Development Index (HDI). Furthermore, in the regions where the CA average is greater, there are lower infant mortality rates, as well as lower birth and violence rates when compared to regions of the globe that have an inferior CA average (Almeida et al., 2011; Bakhiet \& Lynn, 2015; Lynn, Sakar \& Cheng, 2015; Lynn \& Yadav, 2015).

Cognitive abilities (CA) can be defined the same manner as intelligence, a very general mental capacity for planning, rationalizing, problem-solving, abstract thinking, grasping complex ideas and learning quickly (Almeida, 2002; Gottfredson, 1997; Nickerson, et al., 1994). CA affect human behavior, and furthermore, the levels and manners of performance shown in different tasks (Noronha et al., 2001). Nisbett (2013) postulates that the test that measure CA focus on both fluid as well as crystalized intelligence present in

*E-mail: rodrigofocosimazzei@gmail.com

- Submetido: 31/03/2017; Revisado: 22/01/2019; Aceito: 16/01/2020. 
individuals. The first one consists of working memory and attention control (the ability to focus on the more important facet of the problem) and is defined as the ability to learn new things and solve problems. The second one is made up of vocabulary, previous access to information, and a comprehension of how the world works, and is defined as the individual knowledge regarding the nature of the world.

The indicator of quality of life which we investigated and crossed with CA was the motor vehicle fatality rate (called DT, in Brazil) which is done by every state in the federative union, and is represented by the number of deaths in traffic accidents divided by the number of vehicles present, over a given period of time. The amount of these deaths in Brazil is strongly linked to the size of the fleet of existing vehicles in each geographical region. This inference is based on the indicators made available by government agencies (National Transit Department [DENATRAN], 2016a, 2016b; Waiselfisz, 2013, 2014). According to DENATRAN (2016a), the registered motor vehicle fleet in Brazil, as of December, 2014 , was of $86,700,490$, which represented an increase of approximately $144 \%$ in relation to the number of vehicles, registered or not, in 2002, which was of $35,523,633^{1}$. The amount of traffic-related deaths has risen dramatically over the years: in 2002, Brazil registered 18,887 deaths according to DENATRAN $(2002,2003,2004,2005,2006)$. In 2004, the number rose to 43,075 , according to the IT Department of the Unified Health System (Sistema Único de Saúde) (DATASUS, 2016), signifying an increasing of approximately $128 \%$.

It is noteworthy that DT rates are even greater in poor countries such as the ones in Africa. However, in both Europe as well as other wealthier regions with higher quality education, the rates for traffic related deaths are far lower (OMS, 2015). Silva (2003) points out that traffic accidents are more frequent in underdeveloped or developing countries. The Decade of Action for Road Safety 2011-2020, created by the World Health Organization (WHO), brings new proposals for intervention and investments, with a focus on risk factors: speeding, driving under the influence of alcohol, not wearing helmets, seatbelts and harnesses for children; furthermore it suggests improving the safety of vehicles on the road as well as reinforcing emergency response road assistance (WHO, 2015). All these actions are essential for reducing and even reaching the goal of zero auto accidents and deaths.

Silva (2003) details that approximately $90 \%$ of traffic accidents are related directly or indirectly to the driver. In this sense, traffic fatalities can be studied under the guise

1 DENATRAN (the local department of motor vehicles and traffic) considers the following methods of transportation in their monthly census of the number of vehicles: cars, trolleys, lorrys, tractor tucks, pickup trucks, SUVs, rolling chassis, mopeds, vans, motorcycles, scooters, buses, quadricycles, trailers, sidecars, bulldozers, tractors, tricycles, and utilitarian vehicles of different types. Source: DENATRAN (2016a). of prevention with a focus on driver behavior (Silva et al., 2012), since there is a lack of a pattern of characteristics for a good driver, as well as one of psychological attributes which predict casualties in traffic (Silva \& Leite, 2012).

In order to fill these blanks, we investigated if the average of the CA's of the local inhabitants of a geographical region predicts the number of traffic-related deaths in said region and if there are other variables such as populational indebtment (PI) as well as the overall sum of paved roads in bad or terrible conditions (RBT), which when combined with the CA's makes up an analytical model capable of explaining a large part of the DT variation.

The need to analyze the factors which influence traffic safety are fundamental, not only in regard of preventing accidents and deaths, but also in decreasing the economic toll which traffic accidents take on a country. Estimates for many countries, including highly developed nations, show that traffic accidents represent a levy which ranges from 1.3 to $2.5 \%$ of the national GDP (Silva, 2003).

In order to investigate DT in Brazilian states, our first hypothesis was that CA's correlate negatively with traffic fatalities in the states, meaning that the higher a state's CA, the lower its DT would be. We theorized that the populations with the highest average CA score would be better suited for completing a wide range of tasks, including driving vehicles and avoiding accidents.

According to Silva et al. (2012), the causes behind traffic accidents are manifold, with human behavior being the main one. The authors point to the classic study of the American psychologist Lewis Terman, from the first half of the twentieth century, which involved individuals whose Intelligence Quotients (IQ) were scored as being above 140, which revealed that traffic accidents happen less in this gifted group, when compared to the rest of the population. According to Bartilotti et al. (2006), the conductor of a vehicle must possess some fundamental abilities in order to drive the automobile, such as analyzing risk factors, staying focused and attentive, and making decisions. Successfully completing the action of driving a vehicle includes readily solving the problems which may arise in traffic during unforeseen situations.

Traffic demands from the driver a control of his actions, directly relating to the act of displacement, and studies suggest positive associations between CA and a better control of one's awareness. The standard deviation among the response of individuals to visual stimuli correlates negatively with their CA. In other words, a person with a high CA score shows more precision in his response to visual stimuli, when compared with people with lower scores (Jensen, 1992). This low variation in response to people with higher CA can be attributed to greater attention spans, since, by definition, attention is one of the pillars of fluid intelligence (Nisbett, 2013) and consequently of CA. Factors external to the individual can also lower reaction time contributing to the prevention of traffic accidents, such 
as visual cues (Galera et al., 2006) as well as the size of the visual stimulus (Carreiro et al., 2012).

Mani et al. (2013) measured the CA of people before and after hypothetically going into debt, and found a decrease of, on average, ten points in the IQ scores of indebted individuals. The explanation of these results given by Mani et al. (2013) was that going into debt provoked worrying in these people, to the point of generating intrusive thoughts, overloading their ability to focus or their cognitive faculties, damping their performance in a statically significant way during tasks which measured their CA. Our second hypothesis, then, was that the average state population indebtment was positively correlated to the DT of said state.

Hence, the scope of the research based itself on traffic psychology, which according to Rozestraten (1998), has the purpose of improving quality of life, educating people, and preventing traffic accidents, and which has a focus on the conductors, the roadways, and the traffic norms (Silva et al., 2012). As for the roadways, our third hypothesis was that RBT when summed to CA makes up a model capable of analyzing a large portion of DT variation.

\section{METHODS}

Our methodology consisted in a secondary research, in which we combined and correlated data from other primary studies regarding CA, DT, PI and RBT, in the states of Brazil, in 2006, 2009, 2012, and 2015. In order to test the hypothesis of this study, we also utilized both simple and multiple linear regressions to investigate which of the variances of the dependent variable (DT) can be explained by the independent variables (CA, PI and RBT). According to Dancey \& Reidy (2006), it is acceptable to establish casual relations between the variables studied in correlational lines. However, it is necessary to measure the variables in different points in time. Thus, we utilized the variables which concerned this study in different times in order to test if there was indeed a relation of causation among them.

The average score for the CA of the citizens of each of the 27 Brazilian states were gathered from the average scores in Mathematics, Reading, and Science obtained by fifteen year old students on the Progamme for International Student Assessment (PISA) (Organisation for Economic Co-operation and Development [OECD], 2016). Many authors have used students' PISA scores as representatives of the CA of their respective homelands (Kaufman et al., 2012; Lynn, 2010; Lynn et al., 2015; Meisenberg \& Lynn, 2011; Rindermann, 2007; Templer, 2012). Furthermore, the academic skills that the PISA tests require from students are part of the taxonomical elements of general intelligence, as proposed by Carrol (1993).

Therefore, CA's were measured in the following manner:

- The average PISA scores from each state, from the years of 2006, 2009, and 2012, were computed by taking the average of plausible values from the Mathematics, Reading, and Science assessments from the years cited (Table 1).

We also employed the weighed arithmetic mean for the PISA scores from the years cited, in accordance with the sample size from each year, for the states. Furthermore, we used the average PISA scores with their respective standard deviations which were transformed into a relative proportion (index number or PISA Index) so that the differences between the students' $C A$ from each state could be visualized more clearly, and as for the other variables in this study, had their values in a metric with a base-100 as to simplify the comparisons made between the variables (Table 2). As a reference, the state with the biggest $\mathrm{CA}$ average score was given the base- 100 value and the other states had their scores computed using this as a reference. This computation was done utilizing a simple Rule of 3 cross-multiplication and is defined as an index number (Sartoris, 2008).

We chose PISA, not another form of evaluation such as the Exame Nacional do Ensino Médio (ENEM), as we presumed that the individuals who take ENEM are a select public of students who will most likely enter a higher learning institution. PISA, on the other hand, encompasses all of the students finishing secondary education and therefore better encapsulates the social-educational complexities of each state's population.

The average indebtment of the individual states was measured according to the following indicators presented below:

- As a representative of populational indebtment (PI): Number of "bounced" checks due to insufficient funds for every thousand processed ones. In other words, the amount of checks that could not be processed due to insufficient funds for every thousand checks which were, with said amount being divulged by the Bank of Brazil. We utilized this as an indicator of non-compliance since it consists in a measure of indebtment that contemplates all the states in the years of 2006, 2009, and 2012 (SERASA, 2016). Just as we did with CA, we utilized the average for each year and a mean of three analyzed years. (Table 3).

- Percentage of indebtment families (IFA), in Brazilian states, in 2015 (FECOMERCIO, 2015). We utilized this as a second complementary estimate to the PI (Table 3 ). 
Table 1

Pisa score in Brazil's 26 states and Federal District (FD) of Brasilia

\begin{tabular}{|c|c|c|c|c|c|c|c|c|c|}
\hline \multirow{2}{*}{$\begin{array}{l}\text { States or } \\
\text { FD }\end{array}$} & \multicolumn{3}{|c|}{2006} & \multicolumn{3}{|c|}{2009} & \multicolumn{3}{|c|}{2012} \\
\hline & $n$ & $M$ & $S D$ & $n$ & $M$ & $S D$ & $n$ & $M$ & $S D$ \\
\hline Rondônia & 11.873 & 395.83 & 69.90 & 13.346 & 391.82 & 70.68 & 16.599 & 390.38 & 67.43 \\
\hline Acre & 4.382 & 356.31 & 84.07 & 3.966 & 362.93 & 67.48 & 8.579 & 373.85 & 69.35 \\
\hline Amazonas & 18.925 & 361.75 & 86.96 & 39.422 & 370.93 & 73.75 & 37.385 & 371.16 & 68.90 \\
\hline Roraima & 2.910 & 385,72 & 78.44 & 2.598 & 365.14 & 72.81 & 5.971 & 371.30 & 81.01 \\
\hline Pará & 35.982 & 391.02 & 86.60 & 52.574 & 375.97 & 79.29 & 60.780 & 374.66 & 71.78 \\
\hline Amapá & 4.023 & 366.12 & 83.27 & 5.252 & 372.53 & 67.19 & 8.063 & 379.48 & 70.28 \\
\hline Tocantins & 12.466 & 362.36 & 85.29 & 15.313 & 382.11 & 80.09 & 19.570 & 374.88 & 77.22 \\
\hline Maranhão & 43.507 & 330.13 & 93.49 & 59.041 & 403.98 & 73.42 & 74.662 & 349.06 & 81.32 \\
\hline Piauí & 16.834 & 384.63 & 79.39 & 25.626 & 373.95 & 80.94 & 36.940 & 392.50 & 80.86 \\
\hline Ceará & 67.419 & 381.35 & 95.16 & 110.031 & 375.85 & 82.56 & 108.284 & 379.86 & 82.73 \\
\hline Rio Grande do Norte & 26.195 & 364.10 & 86.38 & 36.661 & 371.02 & 83.03 & 31.980 & 385.51 & 82.41 \\
\hline Paraíba & 20.630 & 389.95 & 93.46 & 34.397 & 384.93 & 84.07 & 44.110 & 401.79 & 83.95 \\
\hline Pernambuco & 55.935 & 355.10 & 87.24 & 84.571 & 380.55 & 86.64 & 96.126 & 366.83 & 71.75 \\
\hline Alagoas & 22.496 & 375.24 & 84.56 & 22.566 & 354.28 & 84.21 & 30.996 & 344.87 & 70.83 \\
\hline Sergipe & 11.154 & 402.24 & 100.82 & 20.027 & 372.22 & 73.73 & 22.576 & 383.12 & 77.11 \\
\hline Bahia & 100.825 & 362.85 & 77.34 & 132.589 & 381.51 & 83.62 & 148.526 & 374.57 & 83.19 \\
\hline Minas Gerais & 224.682 & 407.29 & 92.31 & 182.653 & 384.93 & 84.07 & 260.598 & 414.77 & 77.88 \\
\hline Espirito Santo & 29.237 & 403.24 & 94.55 & 40.180 & 355.49 & 74.52 & 41.091 & 421.57 & 87.02 \\
\hline Rio de Janeiro & 126.717 & 410.52 & 97.11 & 156.865 & 408.06 & 98.47 & 194.140 & 394.21 & 78.32 \\
\hline São Paulo & 438.041 & 383.39 & 80.75 & 583.661 & 408.81 & 82.70 & 591.268 & 413.97 & 79.43 \\
\hline Paraná & 113.736 & 418.81 & 93.03 & 122.045 & 417.23 & 83.59 & 153.894 & 412.58 & 83.80 \\
\hline Santa Catarina & 61.893 & 433.80 & 88.47 & 62.414 & 428.24 & 78.39 & 69.025 & 417.72 & 79.10 \\
\hline Rio Grade do Sul & 103.154 & 421.90 & 78.49 & 110.671 & 423.89 & 82.88 & 127.039 & 419.29 & 70.24 \\
\hline Mato Grosso do Sul & 20.586 & 400.93 & 81.26 & 22.743 & 375.97 & 79.29 & 28.687 & 416.21 & 73.51 \\
\hline Mato Grosso & 25.481 & 369.72 & 78.51 & 33.411 & 422.25 & 94.02 & 43.129 & 375.01 & 76.63 \\
\hline Goiás & 59.893 & 393.67 & 83.56 & 71.383 & 389.26 & 72.53 & 63.873 & 388.04 & 74.85 \\
\hline Distrito Federal & 24.225 & 429.85 & 109.12 & 28.905 & 438.95 & 80.42 & 36.096 & 422.17 & 84.11 \\
\hline Mean & 62.341 & 387 & 87 & 76.774 & 388 & 80 & 87.407 & 389 & 77 \\
\hline
\end{tabular}

Note. For PISA score, the means (M) and Standard deviations (SD) consisted of the average standard deviation of the scores of students in Mathematics, Reading and Science, in the years analyzed. Source: OCDE (2016)

In order to analyze the deaths in traffic and road conditions, we utilized the following estimates, respectively:

- Traffic-related deaths (DT): which consists in the number of traffic deaths, divided by the vehicular fleet in the years 2006, 2009, and 2012, and the average DT for said years (DENATRAN, 2016b; Waiseflisz, 2013, 2014) (Table 3).

DT can be estimated by a variety of parameters and one of them consists in the number of deaths calculated in a determined period of time. A more accurate way of comparing the number of deaths in a geographical region in relation to other places consists in constructing a fraction in which the numerator is the number of traffic-related deaths and the denominator is the territory's vehicular fleet (Waiselfisz, 2013, 2014).

- Classification of the general state of the highways, in bad or very bad situation, in percentage (RBT). The totality of Brazil's road network, both paved and unpaved, and considering federal, state and municipal roads, has an extension of 1,720,607 kilometers. The paved highways of Brazil have a total length of 213,229 km. The roads analyzed in this study, namely the paved ones, were classified into five categories, by the National Transport Confederation (CNT): Excellent, Good, Regular, Bad or Very Bad (CNT, 2015). We selected only those which fell under the category of 'Bad or Very Bad' in order to classify the highways (Table 3). 
Table 2

Average Pisa score in Brazil's 26 states and Federal District (FD) of Brasilia

\begin{tabular}{|c|c|c|c|c|c|}
\hline States and FD & $n$ & $M$ & $D P$ & PISA Index ${ }^{a}$ (base: $D F=100$ ) & $S D$ related to the PISA Index \\
\hline Rondônia & 41.818 & 392.67 & 69.34 & 91.25 & 16.11 \\
\hline Acre & 16.927 & 364.36 & 73.64 & 84.67 & 17.11 \\
\hline Amazonas & 95.731 & 367.95 & 76.54 & 85.51 & 17.79 \\
\hline Roraima & 11.480 & 374.05 & 77.42 & 86.92 & 17.99 \\
\hline Pará & 149.336 & 380.55 & 79.22 & 88.43 & 18.41 \\
\hline Amapá & 17.337 & 372.71 & 73.58 & 86.61 & 17.10 \\
\hline Tocantins & 47.350 & 373.12 & 80.87 & 86.71 & 18.79 \\
\hline Maranhão & 177.210 & 361.06 & 82.75 & 83.90 & 19.23 \\
\hline Piauí & 79.399 & 383.69 & 80.40 & 89.16 & 18.68 \\
\hline Ceará & 285.733 & 379.02 & 86.81 & 88.08 & 20.17 \\
\hline Rio Grande do Norte & 94.836 & 373.54 & 83.94 & 86.81 & 19.51 \\
\hline Paraíba & 99.138 & 392.22 & 87.16 & 91.15 & 20.25 \\
\hline Pernambuco & 236.632 & 367.49 & 81.88 & 85.40 & 19.03 \\
\hline Alagoas & 76.058 & 358.13 & 79.87 & 83.22 & 18.56 \\
\hline Sergipe & 53.757 & 385.86 & 83.89 & 89.67 & 19.49 \\
\hline Bahia & 381.940 & 372.98 & 81.39 & 86.67 & 18.91 \\
\hline Minas Gerais & 667.933 & 402.33 & 84.75 & 93.50 & 19.70 \\
\hline Espirito Santo & 110.508 & 393.43 & 85.37 & 91.43 & 19.84 \\
\hline Rio de Janeiro & 477.722 & 404.26 & 91.30 & 93.94 & 21.22 \\
\hline São Paulo & 1.612 .969 & 402.06 & 80.96 & 93.43 & 18.81 \\
\hline Paraná & 389.675 & 416.21 & 86.81 & 96.72 & 20.17 \\
\hline Santa Catarina & 193.332 & 426.59 & 81.99 & 99.13 & 19.05 \\
\hline Rio Grade do Sul & 340.865 & 421.69 & 77.20 & 98.00 & 17.94 \\
\hline Mato Grosso do Sul & 72.016 & 397.70 & 78.02 & 92.42 & 18.13 \\
\hline Mato Grosso & 102.021 & 389.00 & 83.05 & 90.40 & 19.30 \\
\hline Goiás & 195.148 & 390.33 & 76.98 & 90.71 & 17.89 \\
\hline Distrito Federal & 89.226 & 430.32 & 91.22 & 100.00 & 21.20 \\
\hline Mean & 226.522 & 388 & 81 & 90 & 19 \\
\hline
\end{tabular}

Note. The mean (M) of Standard Deviation (SD) consisted of the average standard deviation of the scores of students in Mathematics, Reading and Science, in the years analyzed.

a The PISA Index referred to the proportion of students'average scores, from each FU, based on the PISA average of the Federal District (base: FD = 100). Source: OCDE (2016).

\section{RESULTS}

We correlated the average of the CA of the population of states in Brazil with DT of the states. CA's were obtained by calculating the average of PISA scores of FU students, and DTs were calculated by dividing the number of annual deaths in traffic accidents by the number of vehicles. Considering the average of the variables in three distinct points in time, namely, 2006, 2009 and 2012, we got $\mathrm{r}=-0.71, p<0.001$ (Table 4). Therefore, we confirmed our first hypothesis, that there is a positive correlation between CA and DT, in Brazilian states.

The PI of states was correlated with DT, for the years of 2006, 2009 and 2012 and for the average of those years. Considering the average of the years 2006, 2009 and 2012, $r=0.61$ was found, $p=0.001$ (Table 5). Therefore, we confirmed our second hypothesis, that the PI does indeed correlates positively with the DT.

We calculated the correlations between RBT and DT in the states. Although they were positive, we did not find any statistically significant correlations between RBT and the average T DT in the years analyzed: $r=0.19, p=0.35$ (Table 6). Thus, we do not confirm our third hypothesis.

All correlations between CA and states' average debt were negative. For the average of 2006, 2009 and 2012, between CA and PI, we found $r=-0.58, p<0.001$ and, between CA and IFA, $r=-0.59, p<0.001$ (Table 7). 
Table 3

PISA Index, population and family indebtedness, state of the highways in bad or terrible conditions and rates for traffic related deaths

\begin{tabular}{|c|c|c|c|c|c|c|}
\hline States and FD & $\begin{array}{c}\text { PISA Index a } \\
\text { (base: } \mathrm{DF}=100 \text { ) }\end{array}$ & $\begin{array}{l}\text { SD related the } \\
\text { PISA Index }\end{array}$ & $\mathbf{P I}^{\mathbf{b}}$ & IFA $^{\mathrm{c}}$ & RBT $^{d}$ & DT $^{\mathrm{e}}$ \\
\hline Rondônia & 91.25 & 16.11 & 42.15 & 37.30 & 7.65 & 58.81 \\
\hline Acre & 84.67 & 17.11 & 81.76 & 27.50 & 24.15 & 49.73 \\
\hline Amazonas & 85.51 & 17.79 & 28.46 & 38.10 & 27.95 & 51.26 \\
\hline Roraima & 86.92 & 17.99 & 101.81 & 32.60 & 11.25 & 64.21 \\
\hline Pará & 88.43 & 18.41 & 47.49 & 31.80 & 21.65 & 77.81 \\
\hline Amapá & 86.61 & 17.10 & 99.43 & 36.40 & 15.85 & 67.66 \\
\hline Tocantins & 86.71 & 18.79 & 58.14 & 36.20 & 15.50 & 69.03 \\
\hline Maranhão & 83.90 & 19.23 & 73.96 & 36.00 & 13.90 & 93.20 \\
\hline Piauí & 89.16 & 18.68 & 58.13 & 32.80 & 11.80 & 100.00 \\
\hline Ceará & 88.08 & 20.17 & 29.22 & 28.80 & 10.50 & 66.45 \\
\hline Rio Grande do Norte & 86.81 & 19.51 & 52.02 & 27.70 & 11.70 & 43.97 \\
\hline Paraíba & 91.15 & 20.25 & 55.08 & 27.30 & 10.70 & 71.88 \\
\hline Pernambuco & 85.40 & 19.03 & 21.48 & 28.40 & 12.40 & 58.31 \\
\hline Alagoas & 83.22 & 18.56 & 53.41 & 32.50 & 2.10 & 92.34 \\
\hline Sergipe & 89.67 & 19.49 & 66.50 & 28.40 & 16.50 & 70.30 \\
\hline Bahia & 86.67 & 18.91 & 32.04 & 29.50 & 9.75 & 55.44 \\
\hline Minas Gerais & 93.50 & 19.70 & 19.32 & 25.00 & 11.60 & 34.88 \\
\hline Espirito Santo & 91.43 & 19.84 & 21.79 & 25.00 & 16.60 & 48.10 \\
\hline Rio de Janeiro & 93.94 & 21.22 & 18.53 & 27.00 & 8.50 & 36.29 \\
\hline São Paulo & 93.43 & 18.81 & 16.02 & 23.90 & 1.60 & 20.27 \\
\hline Paraná & 96.72 & 20.17 & 19.71 & 24.70 & 9.50 & 35.81 \\
\hline Santa Catarina & 99.13 & 19.05 & 18.34 & 22.30 & 12.60 & 32.60 \\
\hline Rio Grade do Sul & 98.00 & 17.94 & 21.21 & 25.30 & 12.20 & 23.87 \\
\hline Mato Grosso do Sul & 92.42 & 18.13 & 21.59 & 24.40 & 9.55 & 44.45 \\
\hline Mato Grosso & 90.40 & 19.30 & 39.87 & 30.60 & 11.80 & 57.59 \\
\hline Goiás & 90.71 & 17.89 & 26.31 & 28.00 & 13.70 & 41.67 \\
\hline Distrito Federal & 100.00 & 21.20 & 29.46 & 30.20 & 2.35 & 26.86 \\
\hline Mean & 90.14 & 18.90 & 42.71 & 29.54 & 12.35 & 55.29 \\
\hline
\end{tabular}

Note a The PISA Index referred to the proportion of students' average scores, from each state of Brazil, based on the PISA average of the Federal District (base: $F D=100) .{ }^{b}$ PI consisted of the average of checks returned for the 2nd time, in the years 2006, 2009 and $2012 .{ }^{c}$ IFA referred to $2015^{d} R B T$ average rating in the bad and terrible categories for paved highways. ${ }^{e} D$ T ratio between the number of deaths in traffic by the vehicle fleet in the states of Brazil (years 2006, 2009 and 2012), base: Piaui = 100. Sources: CNT (2015), DENATRAN (2016b), FECOMERCIO (2015), OCDE (2016), SERASA (2016) e Waiselfisz $(2013,2014)$.

Table 4

Correlations between Pisa score and variation of death rates in traffic (DT) in the 27 states of Brazil

\begin{tabular}{lcccc}
\hline & DT 2006 & DT 2009 & DT 2012 & DT (M) \\
\hline PISA 2006 & $r=-0.53 ;$ & & \\
& $p=0.004$ & & \\
PISA 2009 & & $r=-0.51 ;$ & \\
& & $p=0.006$ & $r=-0.72 ;$ \\
PISA 2012 & & $p<0.001$ & $r=-0.71 ;$ \\
PISA $(M)$ & & & $p<0.001$ \\
\hline
\end{tabular}

Note. PISA student's scores consisted of weighted averages of plausible values in Mathematics, Science and Reading. DTs were calculated by the number of deaths in traffic, divided by the vehicle fleet, in the states of Brazil, in the years 2006, 2009 and 2012. Sources: DENATRAN (2016b), OCDE (2016) e Waiselfisz $(2013,2014)$. 
We calculated two linear regression models. In the first one, we analyzed the impacts of CA on DT, in Brazilian states. CA accounted alone for $50 \%$ of the variation in DT in FU, in the average of the years 2006, 2009 and 2012 $\left(r^{2}=0.50, p<0.001\right)$ (Figure 1).

In the second model, we estimated the influence of PI on DT. The PI alone accounted for $37 \%$ of the variation in DT in FUs, on the average of the years 2006, 2009 and 2012 $\left(r^{2}=0.37, p=0.001\right)$ (Figure 2).

In order to control the reciprocal influences of the two independent variables (CA and PI) on the variation of DT in Brazilian states, we analyzed a multiple linear regression model, in which CA and PI were the independent variables and DT consisted of the dependent variable. This latter model explained $56 \%$ of the variation in DT $\left(r^{2}=0.56\right.$, $p<0.001)$. The CA variable was statistically significant to explain the variation in DT $(p=0.005)$. The PI was not statistically significant to explain the variation in DT ( $p=$ 0.08). The CA and PI variables are collinear, that is, they are redundant for explaining the variation in DT. Due to the collinearity between the independent variables, one must choose, for the formulation of an explanatory model, the best predictor of the variance of the dependent variable. The best predictor was CA. We confirmed the collinearity between CA and PI the test "Colinearity Diagnostics", SPSS, version 23, which showed eigenvalues (eigenvalues)

Table 5

Population indebtedness and variation of death rates in the traffic (DT) of the 27 states of Brazil

\begin{tabular}{|c|c|c|c|c|}
\hline & DT 2006 & DT 2009 & DT 2012 & DT $(M)$ \\
\hline PI 2006 & $\begin{aligned} r & =0.58 \\
p & =0.002\end{aligned}$ & & & \\
\hline PI 2009 & & $\begin{array}{l}r=0.65 \\
p<0.001\end{array}$ & & \\
\hline PI 2012 & & & $\begin{aligned} r & =0.53 \\
p & =0.005\end{aligned}$ & \\
\hline $\mathrm{PI}(M)$ & & & & $\begin{aligned} r & =0.61 \\
p & =0.001\end{aligned}$ \\
\hline IFA $2015^{\text {a }}$ & $\begin{aligned} r & =0.65 \\
p & <0.001\end{aligned}$ & $\begin{aligned} r & =0.60 \\
p & =0.001\end{aligned}$ & $\begin{aligned} r & =0.58 \\
p & =0.002\end{aligned}$ & $\begin{aligned} r & =0.63 ; \\
p & <0.001\end{aligned}$ \\
\hline
\end{tabular}

Note. Population indebtedness (PI) consisted of the average of checks returned for the 2nd time, in years 2006, 2009 and 2012, and represents an estimate of the population indebtedness of each state of Brazil. Traffic accident death rates (DT) consisted of the number of traffic accident deaths divided by the vehicle fleet, in the states of Brazil, in the years 2006, 2009 and 2012 and average (M) of those years. ${ }^{a}$ IFA (percentage of households in debt in 2015) referred to an estimate of indebtedness population of each state of Brazil. Sources: DENATRAN (2016b), FECOMERCIO (2015), SERASA (2016) e Waiselfisz $(2013,2014)$.

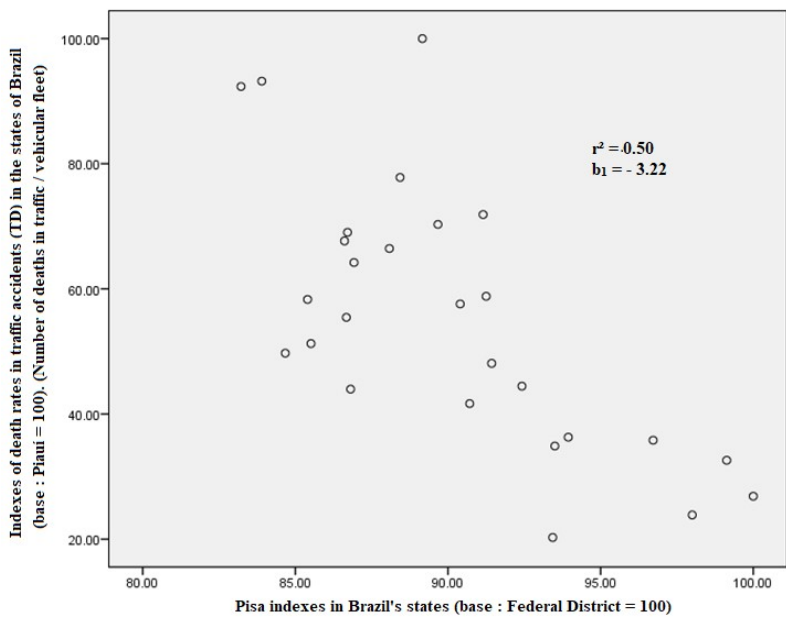

Figure 1. Linear regression of the influence of student scores on PISA on the variation in death rates in traffic accidents, in the 27 states of Brazil. Note. The 2006, 2009 and 2012 averages of the PISA Indexes and DT Indexes were used. Sources: DENATRAN (2016b), OECD (2016) and Waiselfisz $(2013,2014)$.

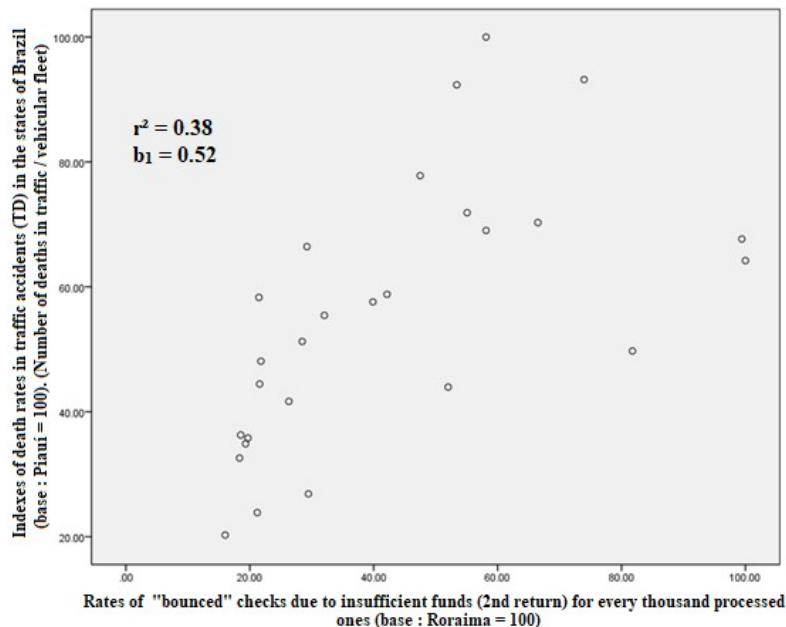

Figure 2. Linear regression of the influence of population indebtedness on a variation in death rates in traffic accidents, in the 27 states of Brazil (26 federal states and the federal district)

Note. They were used as media for 2006, 2009 and 2012 of the Returned Checks Indexes and DT Indexes. Sources: DENATRAN (2016b), SERASA (2016) and Waiselfisz $(2013,2014)$. 
Correlations between the state of the roads in a bad or terrible situation (RBT) and the traffic death rates (DT) in the states of Brazil

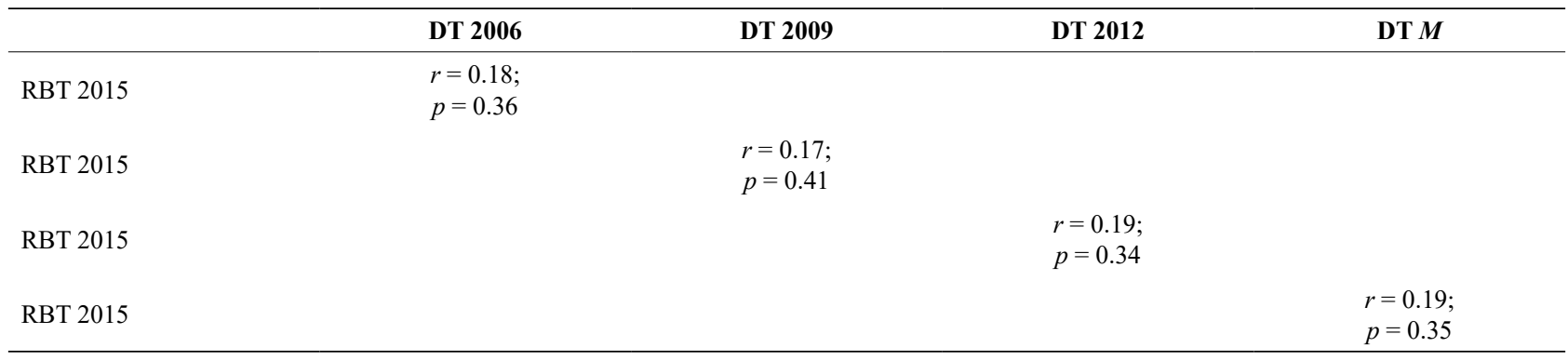

Note. Traffic accident death rates (DT) consisted of the number of deaths from traffic accidents traffic, divided by the vehicle fleet, in the states of Brazil, in the years 2006, 2009 and 2012 and average (M) of those years. The state of the roads in a bad or very bad situation (RBT) represented the average of the states of the highways paved, in each state of Brazil, classified in bad or terrible conditions. Sources: CNT (2015), DENATRAN (2016b) e Waiselfisz (2013, 2014).

Table 7

Correlations between PISA scores and population indebtedness in the states of Brazil

\begin{tabular}{|c|c|c|c|c|c|}
\hline & PI 2006 & PI 2009 & PI 2012 & PI $(M)$ & IFA $^{\text {a }}$ \\
\hline PISA2006 & $\begin{array}{l}r=-0.47 \\
p=0.013\end{array}$ & & & & $\begin{array}{l}r=-0.57 \\
p=0.002\end{array}$ \\
\hline PISA2009 & & $\begin{array}{c}r=-0.42 \\
p=0.03\end{array}$ & & & $\begin{array}{c}r=-0.28 \\
p=0.17\end{array}$ \\
\hline PISA2012 & & & $\begin{array}{c}r=-0.49 \\
p=0.01\end{array}$ & & $\begin{array}{l}r=-0.67 \\
p<0.001\end{array}$ \\
\hline $\operatorname{PISA}(M)$ & & & & $\begin{array}{l}r=-0.58 \\
p=0.001\end{array}$ & $\begin{array}{l}r=-0.59 \\
p=0.001\end{array}$ \\
\hline
\end{tabular}

Note. PISA student's scores consisted of weighted averages of plausible values in Mathematics, Science and Reading. Population indebtedness (PI) consisted of the average of checks returned for the 2nd time, in the years 2006, 2009 and 2012 and the average of those years, and represents an estimate of the indebtedness population of each state of Brazil. aIFA (percentage of households in debt in 2015) referred to an estimate of the population indebtedness of each state of Brazil Sources: FECOMERCIO (2015), OCDE (2016) e SERASA (2016).

very close to zero (eigenvalues $=0.001)$ and values of the condition index (condition index) greater than 30 (condition index $=59.83$ ).

We did not use the RBT variable to construct the multiple linear regression model for two reasons: the correlations between RBT and DT, although positive, were not statistically significant; when adding the RBT variable to the multiple linear regression model, there was no impact on the adjusted coefficient of determination $\left(r_{\mathrm{a}}{ }^{2}\right)$ of the model (Maroco, 2014) .

\section{DISCUSSION}

\section{Cognitive abilities (CA), population indebtedness (PI) and death rates in traffic accidents (DT) in the federal units (FU) in Brazil}

CA's have negative and statistically significant correlations with DT, in several different years (Table 4). These results are in accordance with several studies that found that the average CA of the inhabitants of a zone predicts their respective social indicators, including different types of deaths, meaning that states or nations with higher
CA averages generally have better social indicators (Almeida et al., 2011; Bakhiet \& Lynn, 2015; Lynn et al., 2015; Lynn \& Yadav, 2015).

Silva (2003) displayed, through epidemiological and experimental studies, that there are several behaviors strongly related to the increase in traffic accidents, fatal or not. These behaviors, which were also highlighted by the Decade of Action for Traffic Safety (2011 - 2020) (WHO, 2015), are: not wearing safety equipment (helmet and seat belt), drunk driving, breaking speed limits and using a device when driving a vehicle. Even using phones characterized 
as "hands-free" when driving is a risky behavior, since the caller, not in the actual vehicle, can put the driver at a much higher risk than a passenger could, due to the fact the external caller requires the driver's attention, without considering the critical moments inherent to traffic (Silva, 2003).

In this sense, as suggested by Silva (2003), it would be vital to differentiate groups according to the risks in which they are exposed to traffic. It is assumed, based on the negative and statistically significant correlations (Table 4) between CA and DT, that people or populations with lower CA averages probably have high rates of risk behaviors, as shown in the previous paragraph. On the other hand, people or populations with higher CA have lower rates of risk behaviors and, therefore, seem to create a shield or greater protection for themselves, in relation to auto accidents.

Furthermore, going from the premise that CA's refer to human skills (Almeida, 2002), such as the ability to think and solve problems on the part of individuals (Nickerson et al., 1994) and to plan (Gottfredson, 1997), it is inferred that CA's affect human behavior and, fundamentally, their levels and forms of performance (Noronha et. al., 2001). Thus, individuals with higher CA scores are involved in fewer traffic related deaths than the rest of the population (Silva, et al., 2012). This statement was confirmed by the present study, in which, for example, an increase of ten points in the PISA (CA) index predicts a decrease of about $32 \%$ in DT of FU in Brazil (Figure 1).

Among the various causes of traffic accidents, there is human behavior (Silva et al., 2012) and, related to human behaviors, are CA's, which encompass, according to Nisbett (2013), the knowledge stored about the nature of the world (crystallized intelligence); the skills to learn something new (the ability to store knowledge in long-term memory) and to solve problems, elements that define fluid intelligence, which depend on attention control (ability to focus on the most important aspect of a problem) and the capacity of working memory (mental space where thinking occurs). Such skills are fundamental for driving cars, with regard to assessing risks, being attentive and focused (Bartilotti et al., 2016).

In addition, people or populations with greater CA, due to having greater knowledge of the nature of the world, probably know more about traffic safety standards and, therefore, comply with these laws more effectively, preventing accidents and deaths more effectively in traffic. On the other hand, these individuals or groups with a higher mean of CA have greater attention control, a fundamental quality for a good performance in traffic. According to Jensen (1992), there are moderate and negative correlations between the CA of individuals and the standard deviation of reaction time to visual stimuli, which may indicate that people with better CA have better control of their own attention, since their responses to visual stimuli have smaller variances, that is, they are more accurate.
Galera et al. (2006) and Carreiro et al. (2012) highlighted the role of visual cues in decreasing the reaction time to visual stimuli and in improving the attention of individuals, indicating that environmental factors can positively influence the subjects' attention levels. PI, unlike visual cues, is possibly an environmental factor that impairs the levels of individual attention and, consequently, of human populations. Mani et al. (2013) found that being in debt overburdened people's attention resources, significantly impairing their performance in tasks that measured their CA. The authors' explanation was that the concern, originated by indebtedness, overloaded the individuals' cognitive resources, especially those related to attention, decreasing their performance in cognitive tasks.

There are strong relationships between the level of attention and the cognitive performance of individuals. Even a person's debts can cause damage to his attention and concentration (Mani et al., 2013) which can lead to worse performance in tasks such as driving a vehicle and, consequently, giving rise to traffic deaths.

Indebtedness seems to impair the attention and other cognitive processes of individuals, to the point of decreasing their performance in tasks such as driving and, consequently, raising DT (Table 5). Like CA, PI is a hidden factor, which explains a large part $(37 \%)$ of the variation in DT among Brazilian FUs (Figure 2). Attention, which is fundamental for a good performance of drivers in traffic (Silva, 2003), consists of an underlying or intrinsic element to CA and PI. This way, impaired attention, whether due to external factors, such as a call to the cell phone, or internal, such as a concern arising from debt, can impact the quality of traffic, in addition to causing accidents and deaths.

The impact of CA on the variation in DT $\left(b_{1}=-3.22, p\right.$ $<0.001$ ) (Figure 1) was greater than the influence of PI on the variation in TOT $\left(b_{1}=0.52, p=0.001\right)$ (Figure 2$)$. This can be explained by the fact that CA's are related not only to the attention of individuals, but also to greater knowledge about the nature of the world such as traffic legislation (Silva \& Alchieri, 2008) and, consequently, to behaviors related to greater traffic safety and prevention such as wearing seat belts or helmets, not talking on a cell phone while driving, respecting speed limits and not driving while drunk.

When we control the reciprocal influences of the independent variables (CA and PI) and calculate their impacts on DT, we find that only CA's were statistically significant in explaining the variance of DT, although PI contributed to an increase in the explanation of the model (there was a change in the adjusted determination coefficient $\left(r_{\mathrm{a}}{ }^{2}\right)$, which varied from 0.48 to 0.52 , when the variable PI was added to the regression model).

The reduced impact of PI on the variance of DT, when controlled by CA, can be explained for three reasons. The first consists of the fact that $\mathrm{CA}$, as previously discussed, 
is related both to preventive behavioral aspects, as well as to better control of attention, and PI is related only to this second cognitive aspect, that is, to an attention deficit.

The second reason can be attributed to the fact that indebtedness affects people or groups differently. Individuals or populations with lower CA averages are more vulnerable to the damaging effects of indebtedness. Mani et. al. (2013) found that farmers with higher per capita income suffer less impact on their cognitive skills arising from debt than their lower income peers. CA's are positively related to income (Vanhanen, 2014). Populations or people with higher CA are more protected from the deleterious effects of indebtedness. The third reason is the fact that populations with higher CA averages normally have lower debt ratios (Table 7) and, therefore, suffer less impact related to this social malaise.

\section{The state of the highways in bad or terrible conditions (RBT) and other factors that may influence the variation in traffic death rates (DT) between the federal units (FU) in Brazil.}

Among the limitations of this study is the fact that Brazilian paved highways represent only $12.4 \%$ of the country's road network (CNT, 2015). Research that also considers unpaved roads may find higher and significant correlations between RBT and DT, since we assume that, in the context of Traffic Psychology, preventive behaviors of individuals, compliance with safety rules and good road conditions are fundamental factors for better traffic safety and, consequently, for a reduction in DT.

Although this study investigates only the influences of $\mathrm{CA}, \mathrm{PI}$ and RBT on DT, there are other variables that can interfere in the variation of this social problem, such as the moral disengagement of individuals (Luiza Neto el at., 2012), gender, since in attention tests, the female average is usually slightly higher than the male average (FloresMendoza et al., 2013), the advanced age of the conductors (Gibb et al., 2016), the perceptual-sensory deficits (Evans \& Ginsburg, 1982; Santos et al., 2003; Schiffman, 2005; Tredici \& Ivan, 2008), vitamin A deficiency (Schiffman, 2005), the amount of insufficient sleep for drivers (Soares \& Almondes, 2012), environments with few visual cues (Mckee \& Smalman, 1998), the use of new technologies such as digital mirrors in automobiles (Gibb et al., 2016; Lange et.al., 2016) and, still, locomotion at high altitudes or excessive smoking before driving, which can result in hypoxia (Schiffman, 2005; Gibb et al., 2016).

Furthermore, data from the Traffic Engineering Company (TEC) report a decrease in traffic accidents in 2015 compared to 2014 in the state of São Paulo (Gomes, 2016), which can be explained by three perspectives: (a) the decrease in the speed limit on highways in the period and (b) the increase in fines - these first two acting as coercive and preventive measures against traffic accidents - and, (c) the economic crisis, which, in this aspect, also has a positive effect, decreasing the fleet of vehicles in traffic and, therefore, the chances of accidents occurring.

\section{CONCLUSIONS AND FINAL REMARKS}

Despite traffic deaths having several causes, the population CA explained alone, in the average of the years 2006, 2009 and 2012, 50\% of the variation of this social ill among Brazilian FUs. Therefore, CA can be considered an explanatory construct of the variation of traffic deaths between states of a country, since we assume that individuals or populations with higher CA have lower rates of risky traffic behaviors and higher levels of care, essential factors for the prevention of traffic accidents.

In addition, social aspects such as population indebtedness predicted, in the averages of the years 2006, 2009 and $2012,37 \%$ of that variation. Individuals concerned by the fact that they are in debt, even though they have excellent skills to drive a vehicle, may have reduced attention and, consequently, perform poorly in driving a car, increasing the rates of traffic deaths. This way, both the decrease in PI and the improvement in CA can reduce DT.

Additional research must be carried out, so that a model can be elaborated that includes other explanatory variables in the prediction of these deaths or analyzes a larger sample of a nation's land roads. CA, when combined with indebtedness, predicted $56 \%$ of the variation in the rate of deaths in traffic accidents in Brazilian states. This explanatory power may be more robust in another model of more comprehensive analysis, if other parameters are taken into account, such as gender, driving experience of drivers, conditions or year of manufacture of vehicles, age of drivers, weather conditions (cloudy, night or high altitudes), the amount of sleep of drivers involved in accidents, visual impairments to distinguish colors or neural injuries from drivers, consumption of alcoholic beverages or other drugs when driving and even disengagement morality by the one who drives a car.

CA's represent a central construct to study the social indicators of a society and any process or policy of social change must take into account the implications of this human attribute for the quality of life of the population of a geographical region and the social, environmental, social and biological factors that can influence CA. Therefore, it is necessary to investigate what factors can influence people's CA: genetics, nutrition, access and educational quality, degrees of interest of individuals in acquiring knowledge, social perceptions about $\mathrm{CA}$, among others. 


\section{REFERENCES}

Almeida, L. S. (2002). As aptidões na definição e avaliação da inteligência: $\mathrm{O}$ concurso da análise factorial [Aptitudes in the definition and evaluation of the intelligence: Contributions of fator analysis]. Paidéia, 12(23), 5-17.

Almeida, L. S., Lemos, G., \& Lynn, R. (2011). Regional differences in intelligence and percapita incomes in Portugal. Mankind Quartely, 52 (2), 213-221.

Bakhiet, S. A. F., \& Lynn, R. (2015). Regional differences in intelligence in Sudan. Intelligence, 50, 150-152.

Bartilotti, C., Scopel, E. J., \& Gamba, P. C. (2016). Avaliação psicológica de condutores de veículos terrestres no Brasil [Psychological assessment of land vehicle drivers in Brazil] O Portal dos psicólogos. http://www.psicologia.pt/artigos/ textos/A0315.pdf.

Carreiro, L. R. R., Haddad H., \& Baldo, M. C. V. (2012). Componentes sensoriais e atencionais do tempo de reação: Efeitos do tamanho, excentricidade e previsibilidade de estímulos visuais [Sensory and attentional components of reaction time: effects of the size, eccentricity and predictability of visual stimuli]. Psicologia: Teoria e Pesquisa, 28 (2), 133-140.

Carroll, J.B. (1993). Human cognitive abilities: A survey of factoranalytic studies. Cambridge University Press.

Confederação Nacional de Transporte. (2015). Pesquisa CNT de Rodovias 2015 [CNT highway survey 2015]. http://pesquisarodoviascms.cnt.org.br/Relatorio\%20Geral/ PESQUISACNT2015BAIXA.pdf

Dancey, C. P., \& Reidy, J. (2006). Estatística sem Matemática para Psicologia [Statistics without maths for psychology] (3a ed.). Artmed.

Departamento de Informática do Sistema Único de Saúde do Brasil (DATASUS, 2016). Acesso às estatísticas DATASUS [Access to DATASUS statistics]. http://www.vias-seguras.com/ os_acidentes/estatisticas/estatisticas_nacionais/estatisticas do ministerio da saude/acesso as estatisticas datasus

Departamento Nacional de Trânsito (2002). Anuário do Denatran: acidentes 2002 [Denatran Yearbook: Accidents 2002]. http:// www.vias-seguras.com/os_acidentes/estatisticas/estatisticas nacionais/estatisticas_do_denatran/anuarios_estatisticos_do_ denatran/anuario do denatran acidentes 2002

Departamento Nacional de Trânsito (2003). Anuário do Denatran acidentes 2003 [Denatran Yearbook: Accidents 2003]. http:// www.vias-seguras.com/os_acidentes/estatisticas/estatisticas nacionais/estatisticas_do_denatran/anuarios_estatisticos_do_ denatran/anuario do denatran acidentes 2003

Departamento Nacional de Trânsito (2004). Anuário do Denatran: acidentes 2004 [Denatran Yearbook: Accidents 2004]. http://www.vias-seguras.com/layout/set/print/os acidentes/ estatisticas/estatisticas_nacionais/estatisticas_do_denatran/ anuarios estatisticos do denatran/anuario do denatran acidentes 2004

Departamento Nacional de Trânsito (2005). Anuário do Denatran: acidentes 2005 [Denatran Yearbook: Accidents 2002]. http:// www.vias-seguras.com/os acidentes/estatisticas/estatisticas nacionais/estatisticas do denatran/anuarios estatisticos do denatran/anuario do denatran acidentes $2 \overline{005}$

Departamento Nacional de Trânsito (2006). Anuário do Denatran: acidentes 2006 [Denatran Yearbook: Accidents 2006] . http:// www.vias-seguras.com/os_acidentes/estatisticas/estatisticas nacionais/estatisticas do denatran/anuarios estatisticos do denatran/anuario do denatran acidentes 2006

Departamento Nacional de Trânsito (2016a). Frotas de veículos - 2014 [Vehicle fleets -2014]. https://infraestrutura.gov.br/ component/content/article/115-portal-denatran/8554-frotade-veiculos-2014.html
Departamento Nacional de Trânsito (2016b). Frotas de veículos - 2002 [Vehicle fleets - 2002]. https://infraestrutura.gov. br/component/content/article/115-portal-denatran/8552estat $\% \mathrm{C} 3 \%$ ADsticas-frota-de-ve\%C3\%ADculos-denatran. html

Evans, D. W., \& Ginsburg, A. P. (1982). Predicting age-related differences in discriminating road signs using contrast sensitivity. Journal of the Optical Society of America, 72, $1785-1786$

FECOMERCIO (2015). Radiografia do crédito e do endividamento das familias nas capitais brasileiras. Comparações 2013-2016 [X-ray of credit and indebtedness of families in Brazilian capitals. Comparisons 2013 -2016]. https://www.fecomercio. com.br/public/upload/file/2017/01/30/radiografia do endividamento_das_fam_lias_envio.pdf

Flores-Mendoza, C., Widaman, K. F., Rindermann, H., Primi, R., Mansur-Alves, M., \& Pena, C. C. (2013). Cognitive sex differences in reasoning tasks: Evidence from Brazilian samples of educational settings. Intelligence, 41(1), 70-84

Galera, C., Cavallet, M., Von Grünau, M., \& Panagopoulos, A. (2006). Características Atentivas Reveladas por Dicas Múltiplas Locais e Globais [Attentive characteristics revealed by local and global multiple cues]. Psicologia: Teoria e Pesquisa, 22(3), 327-334.

Gibb, R., Gray, R., \& Scharff, L. (2016). Aviation visual perception: Research, misperception and mishaps. Routledge.

Gomes, P. (2016, Março 22). Número de mortes no trânsito de São Paulo tem a maior queda desde 1998 [Traffic deaths in São Paulo have the biggest drop since 1998]. Folha de São Paulo. http://www1.folha.uol.com.br/cotidiano/2016/03/1752627numero-de-mortes-no-transito-de-sao-paulo-tem-a-maiorqueda-desde-1998.shtml

Gottfredson, L. S. (1997). Mainstream Science on Intelligence: An Editorial With 52 signatories, history, and bibliography. Intelligence, 24(1)13-23.

Jensen, A. R. (1992). The importance of intraindividual variation in reaction time. Personality and Individual Differences, 13(8), 869-881.

Kaufman, S. B., Reynolds, M. R., Liu, X., Kaufman, A. S., \& McGrew, K. S. (2012). Are cognitive $g$ and academic achievement $\mathrm{g}$ one and the same? An exploration of the Woodcock-Johnson and Kaufman tests. Intelligence, 40(2), 123-138.

Lange, F., Haiduk, M., Boos, M., Tinschert, P., Schwarze, A., \& Eggert, F.(2016). Road crossing behavior under traffic light conflict: Modulating effects of green light duration and signal congruency. Accident Analysis and Prevention, 95(Part A), 292-298.

Luiza Neto, I., Iglesias, F., \& Günther, H. (2012). Uma medida de justificativas de motoristas para Infrações de trânsito [A measure of driver's justifications to traffic violations]. Psico, 43(1), 7-13.

Lynn, R. (2010). In Italy, north-south differences in IQ predict differences in income, education and infant mortality. Intelligence, 38 (1), 93-100.

Lynn, R., Sakar, C. \& Cheng, H. (2015). Regional differences in intelligence, income and other socio-economic variables in Turkey. Intelligence, 50, 144-149.

Lynn, R. \& Yadav, P. (2015). Differences in cognitive ability, per capita income, infant mortality, fertility and latitude across the states of India. Intelligence, 49, 179-185.

Mani, A., Mullainathan, S., Shafir, E., \& Zhao, J. (2013). Poverty impedes cognitive function. Science, 341(6149), 976-80.

McKee, S. P., \& Smallman, H. S. (1998). Size and speed constancy. In V. Walshand, \& J. Kulikowski, J. (Eds.), Perceptual 
constancy: Why things look as they do (pp. 373-408). Cambridge University Press.

Meisenberg, G., \& Lynn, R. (2011). Intelligence: A measure of human capital in nations. Journal of Social, Political \& Economic Studies, 36(4), 421-454.

Nickerson, R.S., Perkins, D.N. \& Smith, E.E. (Eds.) (1994). Ensenar a pensar: Aspectos de la aptitud intellectual [Teach thinking: Aspects of intellectual fitness]. Paidós: M.E.C

Nisbett, R. E. (2013). Schooling makes you smarter: What teachers need to know about IQ. American Educator, 37(1),10.

Noronha, A. P. P., Sbardelini, E. T. B., \& Sartori, F. A. (2001). Análise da qualidade de testes de inteligência publicados no Brasil [Quality analysis of intelligence tests published in Brazil]. Psico-USF, 6 (2), 95-104.

Organização Mundial da Saúde (2015). Global Status Report on Road Safety. https://books.google.com.br/books?hl=pt-BR $\& \mathrm{r}=\& \mathrm{id}=\mathrm{wV} 40 \mathrm{DgAAQBAJ} \& \mathrm{oi}=\mathrm{fnd} \& \mathrm{pg}=\mathrm{PP} 1 \& \mathrm{dq}=\mathrm{globa}$ 1+status+report+on+road+safety+2015\&ots=DJZwAYfYnj $\&$ sig $=$ HPEtk-8p_LM01tuZhbeRGpy0oY\#v=onepage\&q= global $\% 20$ status $\% 20$ report $\% 20$ on $\% 20$ road $\% 20$ safety $\% 20$ $2015 \& \mathrm{f}=$ false

Organisation for Economic Co-operation and Development (2016). PISA: Programe for international Student assessment. https:// www.oecd.org/pisa/data/

Rindermann, H. (2007). The g-factor of international cognitive ability comparisons: The homogeneity of results in PISA, TIMSS, PIRLS and IQ tests across nations. European Journal of Personality, 21(5), 667-706.

Rozestraten, R. J. A. (1988). Psicologia do trânsito: Conceitos e processos básicos [Traffic psychology: Basic concepts and processes]. E.P.U.

Santos, N. A.; Simas, M. L. B., \& Nogueira, R. M. T. B. L. (2003). Processamento visual da forma em idosos: Curvas de limiar de contraste para frequências angulares e senoidais [Visual processing of form in the aged: Threshold contrast curves to angular and spatial frequency]. Psicologia: Reflexão e Crítica, 16(2), 271-277.

Sartoris, A. (2008). Estatística e introdução à econometria [Statistics and introduction to econometrics]. Saraiva.

Schiffman, H. R. (2005). Sensação e Percepção [sensation and perception]. LTC.
Serasa Experian. (2016). Indicadores econômicos [Economic indicators]. https://www.serasaexperian.com.br/amplie-seusconhecimentos/indicadores-economicos

Soares, C. S., \& Almondes, K.M. (2012). Sono e cognição: Implicações da privação do sono para a percepção visual e visuoespacial [Sleep and cognition: Implications of sleep deprivation for visual perception and visuospatial]. Psico, 43(1), 85-92.

Silva, F. H. V. C., \& Alchieri, J. C. (2008). Revisão das pesquisas brasileiras em avaliação psicológica de habilidades e inteligência de condutores [A review of Brazilian research on psychological assessment of drivers' abilities and intelligence]. Estudos de Psicologia, 13(1), 57-64.

Silva, J. A. (2003). Psicologia e comportamentos [Psychology and behaviors]. Canavaci.

Silva, J. A., Ribeiro-Filho, N. P. \& Dos Santos, R. C. (2012). Inteligência humana e suas implicações [Human intelligence and its implications]. Temas em Psicologia, 20(1), 155-187.

Silva, S. G. M., \& Leite, U. R. (2012, Julho 22). Avaliação psicológica de motoristas em reabilitação [Psychological assessment in drivers in rehabilitation]. Revista Psicologia. http://www.psicologia.pt/artigos/textos/A0636.pdf

Templer, D. I. (2012). Biological correlates northern-southern Italy differences in IQ. Intelligence, 40(5), 511-517.

Tredici, T. J. \& Ivan, D. J. (2008). Ophthalmology in aerospace medicine. In: J. R. Davis, R. Johnson, J. Tepanek, \& J. A. Fogarty (Eds.). Fundamentals of Aerospace Medicine. Lippincott Williams and Wilkins.

Vanhanen. T. (2014). Global inequality as a consequent of human diversity: A new theory tested by empirical evidence. Ulster Institute for Social Research.

Waiselfisz, J. J. (2013, Janeiro). Mapa da Violência 2013. Acidentes de trânsito e motocicletas [Map of violence 2013. Traffic accidents and motorcycles]. Centro Brasileiro de Estudos Latino-Americanos https://mapadaviolencia.net.br/pdf2013/ mapa2013 transito.pdf

Waiselfisz, J. J. (2014, Julho). Prévia do Mapa da Violência 2014. Os jovens do Brasil [Preview of the map of violence 2014. Young people in Brazil]. Centro Brasileiro de Estudos LatinoAmericanos. Recuperado de http://www.mapadaviolencia.org. br/pdf2014/Mapa2014_JovensBrasil.pdf 